\title{
Asymmetries of state government social distancing policies in the face of COVID-19: political and technical-administrative
}

\section{aspects}

\author{
Ana Karine Pereira 12 \\ Marília Silva Oliveira ${ }^{3}$ \\ Thiago da Silva Sampaio ${ }^{4}$ \\ 1 Universidade de Brasília / Center for Sustainable Development, Brasília / DF - Brazil \\ 2 Universidade de Goiás / Graduate Program in Political Sciences and Graduate Program in Administration, Goiânia / G0 - Brazil \\ 3 Universidade de Brasília / Institute of Political Science, Brasília / DF - Brazil \\ ${ }^{4}$ Universidade Federal do Pampa / Graduate Program in Public Policies, São Borja / RS - Brazil
}

\begin{abstract}
This article aims to analyze the leadership of Brazilian state governments on lockdown and social distancing policies to keep COVID-19 from spreading. It is assumed that the states' policies on this matter are heterogeneous, and their implementation regarding how commercial activities - and others that potentially involve a large concentration of people - is asymmetric. Therefore, the study observed the debates on policy-making processes and on autonomy and federalism to investigate the influence of political or technical-administrative factors on policies adopted at the state level in Brazil. The methodology used content analysis of 134 state norms, mapping the political-party alignment of state governors to the president, analysis of medical and hospital resources of each federation unit based on the National Register of Health Establishments. The emergency context revealed low inter-federative coordination by the federal government, competition among states, and states leadership in crisis management at the local level. The article presents evidence that state governments' leadership cannot be justified by political party alignment with the president. However, there is a correspondence between both the local health system capacity and the rigor of lockdown and social distancing policies, which indicates that, in an intense social disorder situation, technical rationality was preferable to political bargaining.
\end{abstract}

Keywords: COVID-19; lockdown and social distancing policies; federative coordination; decision-making process.

\section{Heterogeneidades das políticas estaduais de distanciamento social diante da COVID-19: aspectos políticos e técnico-administrativos}

Este artigo tem o objetivo de analisar a liderança dos governos estaduais brasileiros na implementação de políticas de distanciamento social para o enfrentamento da disseminação da COVID-19. Pressupõe-se que as políticas de distanciamento social são heterogêneas, apesar da liderança dos governos, ou seja, apresentam certo grau de assimetria nas restrições do funcionamento do comércio e de atividades com potencial de aglomeração de pessoas. Diante disso, foram combinados os debates sobre processo de produção de políticas públicas e sobre autonomia e federalismo, para investigar a influência dos fatores políticos ou técnico-administrativos nas políticas estaduais. Os seguintes procedimentos metodológicos foram utilizados: análise de conteúdo de 134 normativas estaduais; mapeamento do alinhamento político-partidário dos governadores estaduais ao presidente da República; análise dos recursos médico-hospitalares de cada unidade da federação baseada no Cadastro Nacional de Estabelecimentos de Saúde (CNES). O contexto emergencial revelou baixa coordenação interfederativa pelo governo federal, provocando uma competição entre entes federativos e forte liderança estadual na gestão da crise no âmbito local. A pesquisa mostra, por um lado, que as decisões sobre as políticas de distanciamento social não podem ser explicadas por fatores políticos; e por outro, a correspondência entre a capacidade do sistema de saúde local e o nível de rigor das políticas de distanciamento social. Conclui-se que, na atual situação de transtorno social intenso, preferiu-se a racionalidade técnica a barganhas políticas.

Palavras-chave: COVID-19; políticas de distanciamento social; coordenação federativa; processo decisório.

[Translated version] Note: All quotes in English translated by this article's translator. 


\title{
Heterogeneidades de las políticas estatales de distanciamiento social frente a la COVID-19: aspectos políticos y técnico-administrativos
}

\begin{abstract}
Este artículo tiene como objetivo analizar el liderazgo de los gobiernos de los estados brasileños en la implementación de políticas de distanciamiento social para enfrentar la propagación de la COVID-19. Se parte del supuesto de que, a pesar de la existencia de este liderazgo, las políticas de aislamiento social son heterogéneas, con cierto grado de asimetría en las restricciones al funcionamiento del comercio y de actividades con potencial de aglomeración de personas. Se combinaron debates sobre el proceso de producción de políticas públicas, autonomía y federalismo para investigar si los factores políticos o técnico-administrativos influyen en la naturaleza de estas políticas a nivel estatal. Se utilizaron los siguientes procedimientos metodológicos: análisis de contenido de 134 regulaciones de estados; mapeo del alineamiento político-partidario de los gobernadores estatales con el presidente de la República; y análisis de los recursos médicos y hospitalarios de cada unidad de la federación con base en el Registro Nacional de Establecimientos de Salud. El contexto de emergencia reveló una baja coordinación interfederativa del gobierno federal, lo que provocó la competencia entre entidades federales y el fuerte liderazgo estatal en la gestión de la crisis en ámbito local. Por un lado, el artículo presenta evidencia de que las decisiones sobre políticas de distanciamiento social no pueden explicarse por factores políticos; y, por otro, existe una correspondencia entre la capacidad del sistema de salud local y el nivel de rigor de las políticas de distanciamiento social. Se concluye que, en la actual situación de intenso desorden social, se prefirió la racionalidad técnica a las negociaciones políticas.
\end{abstract}

Palabras clave: COVID-19; políticas de distanciamiento; coordinación federativa; proceso de toma de decisiones.

\section{INTRODUCTION}

On March 11, 2020, the World Health Organization (WHO) attributed the status of 'pandemic' to the spread of the coronavirus disease (COVID-19) caused by the recently discovered virus SARS-CoV-2. The status of 'pandemic' was a response of the WHO to the disease's rapid dissemination worldwide and to the "alarming levels of inaction" (Agência Brasil, 2020). Before this measure from the WHO, the Brazilian federal government had published Portaria (Ordinance) 188 enacted on February 3 (2020) by the Brazilian Ministry of Health (MH), and Lei (Law) 13979 on February 6 (2020). ${ }^{1}$ The first regulation declared the situation of a public health emergency of national concern (PHENC). The second followed WHO guidelines, providing measures to tackle public health emergencies. It emphasized social distancing policies, including measures for isolation, ${ }^{2}$ quarantine, ${ }^{3}$ and exceptional and temporary restriction of highways, ports, and airports. In March, the $\mathrm{MH}$ released Ordinance 454 (2020), acknowledging community transmission of COVID-19 in Brazil.

In this scenario, state governments have been actively regulating social distancing policies at the local level. The Federal District was the first region to adopt restrictive measures. On March 11, 2020, the government prohibited events that gathered more than fifty people and determined the closure of private and public schools, universities, and colleges (Decreto n. 40.509, 2020). In the second half of March, all states issued decrees providing social distancing policies to contain the advance of the

\footnotetext{
${ }^{1}$ This law is regulated by Ordinance 356, of March 11 (2020), from the Brazilian Ministry of Health.

${ }^{2}$ According to Law 13979 (2020), isolation measures refer to the "separation of sick or contaminated persons or luggage, means of transport, goods, or postal parcels, from others, in order to avoid contamination or the spread of the coronavirus."

${ }^{3}$ The same law designates quarantine as the "restriction of activities or separation of persons suspected of being infected by persons who are not sick, or the restriction of luggage, containers, animals, means of transport, or goods suspected of being contaminated, in order to avoid possible contamination or the spread of the coronavirus."
} 
pandemic. Despite the rapid and preventive action of the federal government, with emphasis on the MH, President Jair Bolsonaro took a long time to address the nation and, when he did so on March 24, his statement collided with the measures already adopted by the Brazilian states and encouraged by the Ministry of Health.

In this context, debates about measures to deal with the pandemic have become a clash between political and technical arguments. On the political side, President Bolsonaro has criticized quarantine measures that governors and mayors, according to him, "imposed" on the population. For the president, it was necessary to return to normality to avoid the paralysis of economic activities and ensure the maintenance of jobs. The president has blamed governors and mayors for the consequences that social distancing policies bring to the economy. Part of the population has responded in support to the president's perspective, with demonstrations calling for the re-opening of local commerce (Linhares \& Barbon, 2020). Another part of the population, however, are engaged in social distancing to break the transmission of the virus and criticizes a reckless resumption of economic activities. This group is self-isolated and protesting by shouting "Fora Bolsonaro" (Bolsonaro out) from the house windows. Bolsonaro has defended the thesis of "vertical" social distancing (i.e., isolating risk groups and contaminated people), but the federal government did not present a concrete plan to effectively implement such measures, such as testing the population. Also, the president has advocated the use of chloroquine, a medicine that did not show significant effects against COVID-19 in preliminary studies (Estadão, 2020), and has potentially harmful side effects.

The technical side, represented mainly by former health minister Luiz Henrique Mandetta, emphasized the need to follow WHO guidelines and scientific evidence, recommending social distancing policies. This conflict culminated in Mandetta's resignation on March 16, 2020. Nelson Teich, who replaced Mandetta, remained at the head of the ministry for less than a month, under strong pressure from President Bolsonaro to change the protocol for the use of chloroquine (Folha de S. Paulo, 2020).

Against this backdrop, this article analyzes the state governments' leadership in social distancing policies to face the spread of COVID-19. This phenomenon, especially important for contemporary debates in political science and public administration, points to changes in federative relations and to a more prominent role of state governments in policies where competencies are shared between federal and state governments. Despite disputes between President Bolsonaro and the Attorney General's Office (AGU) (Folha de Pernambuco, 2020), the Supreme Federal Court (STF) guaranteed the autonomy of state governments in determining social distancing measures (Pinheiro, 2020), thus maintaining the prominence of the state in the context of the public health crisis.

It is assumed that the social distancing policies in the different states are not homogeneous, i.e., the states apply different restrictions to activities such as commerce and others that may produce agglomeration. The study adopted two perspectives, examining the influence of both political and technical-administrative factors on the implementation of state governments' social distancing policies. As a political factor, the research observed if the state governors support or oppose the president, examining their alignment in the elections and agreement regarding the approach to social distancing measures. As a technical factor, the study observed the capacity of the Brazilian national health system (SUS), at the state level, to tackle the health crisis. The analysis considered the number of intensive care 
doctors per inhabitant; and the number of beds and ventilators available in intensive care units (ICUs). The following questions guided the investigation: do political conflicts with the president influence the nature of the states' social distancing policies? Would these conflicts limit, even if informally, the states' autonomy? Is the level of restrictions imposed on the states' social distancing policies guided by technical rationality supported by available information on the capacity of SUS in each state?

The study adopted content analysis to examine 134 state regulations published between March 11, 2020 (date of the first decree of a Brazilian state), and April 16, 2020 (date of resignation of ex-minister Mandetta). The analysis sought to create categories of social distancing policies and identify the nature of these policies in each state. The study presented dynamic data and demonstrated the evolution of the measures, according to the trends of maintenance or relaxing restrictions. The analysis of the political factor observed whether governors supported President Bolsonaro in the 2018 national election, if they remained aligned with the president during the first year of his term, and whether they adhered to the president's discourse opposing social distancing policies. The study of the technical-administrative factor was based on the analysis of data from the Conselho Nacional dos Estabelecimentos de Saúde (CNES) (national council of health establishment) and information about the medical and hospital resources available in each state.

The following section presents the literature on the health policy-making process in Brazil, connecting it with the debates on autonomy and federalism to support the assumptions and the two research hypotheses. The third section shows and discusses the data collected, and the article's fourth and last section presents the final considerations.

\section{THE HEALTH POLICY-MAKING PROCESS: ASSUMPTIONS AND RESEARCH HYPOTHESES}

Part of the policy-making process involves the government agenda-setting and the phases of formulating and implementing institutional arrangements that will transform policymakers priorities into reality. The agenda-setting process captures how the government distributes attention in a given area, deciding which problems are most important and worthy of government attention (Brasil \& Capella, 2019). As for the institutional arrangement, it may be considered a set of specific rules that regulate political and social relations in a given sector or policy (Gomide \& Pires, 2014).

In Brazil, the agenda-setting regarding health care has been described in the literature from the perspective of a "punctuated equilibrium" - in which long periods of stability are interrupted by environmental disturbances that disseminate new understandings (Baumgartner \& Jones, 2020) - and "incrementalism," characterized by gradual and punctual adjustments resulting from conflicts among actors and limited information and resources (Lindblom, 1959; Pierson, 1993, 1994).

Thus, Menicucci (2007) associates the emergence of SUS with a contextual rupture - the period of re-democratization in Brazil - that allowed an alternative understanding about the government's role in the delivery of health care services. However, there is an inertial component in this context that also helps to explain the emergence of SUS; a component that led to the development of a hybrid system, where public and private forms of health care services coexist. The agenda-setting in this area has been marked in recent years by incremental periods, sometimes disrupted with major changes. For example, immediately after the re-democratization, the health care agenda focused on the structuring of the system (funding strategies and the coordination between centralization and 
decentralization). Later on, there were long periods of settling, disrupted time to time with new changes, such as from 1993 to 1995, when the government's agenda favored primary and preventive care. During this period, the government reformed SUS diversifying the services and incorporating basic actions directed to people in vulnerability (Draibe, 2005; Menicucci, 2014; Menicucci, Costa, \& Machado, 2018; Souza, 2019).

The process of defining priority topics in health has been characterized by the disproportionality from the different branches, with a strong centrality in the federal executive, operating through legislative measures (Brasil \& Capella, 2019). The Ministry of Health (MH), therefore, remains the authority that makes the main decisions in this area (Arretche, 2004).

As for the formulation of institutional arrangements, the Brazilian Federal Constitution of 1988 provides that health care is an issue under the responsibility of the three levels of governments (federal, state, and municipalities) who have to offer different services and play a variety of roles within a highly decentralized system (SUS). These services and roles are not automatically granted, but depend on a calculation regarding the policy costs and the administration and financial capacity of the local, state, or federal entities (Arretche, 1999; Souza, 2004). In this context, the federal government has taken a leading role in the construction of institutional arrangements, coordinating and cooperating to operate the system, creating an environment in which the federal government concentrates the standardization capacities and the municipalities are important actors of implementation (Arretche, 1999; Bichir, 2016; Souza, 2004).

The financial instruments and the regulations of the $\mathrm{MH}$ are designed to build consensus around responsibilities influence these institutional arrangements. The centrality of the federal government in coordinating and inducing cooperation among states and municipalities is a consequence of its role in funding and formulating the national health policy (Arreteche, 2004). The coordination of national actions occurs mainly through ministerial ordinances, conditioning the transfer of federal resources to states and municipalities to their compliance with the objectives of federal policy (Abrucio, 2005; Arretche, 2004).

In the 1990s, the Normas Operativas Básicas (NOB) (basic operating standards) of SUS were created. These standards rationalized and conditioned the transfer of resources to states and municipalities, as well as establishing an evaluation system for health policies. According to Abrúcio (2005), the NOB-96, issued in the 1990s, was the start of an important structuring process in SUS. The standard provided that the three government instances would be responsible for the system, and the federal and state governments would be in charge of promoting the "[...] harmonization, modernization, and integration of SUS" (Abrucio, 2005, p. 58, our translation). The operation of these joint activities occurs through the Comissão Intergestores Bipartite (CIB) (inter-managers bipartite commission), gathering representatives of health managers from municipalities and the state, and the Comissão Intergestores Tripartite (CIT) (inter-managers tripartite commission), formed with representatives from municipal, state, and federal health managers.

In the 2000s, the program Pacto pela Saúde (pact for health) was consolidated. It was an incremental evolution in comparison with the other rules that regulated the relationships about the three levels of government regarding SUS. The program aimed to promote managerial innovation and social equity, in addition to redefining collective responsibilities. Despite occurring in a tripartite arena (in the scope of the CIT), and counting on an important influence from states and municipalities, the 
federal government maintained the faculty of policy formulation, which reinforces the dominant role of the Union in the health sector (Menicucci et al., 2018)

The analysis of the Brazilian states and municipalities performance in the face of the COVID-19 pandemic reveals a potential period of disruption, where external factors - the rapid spread of the disease and consequent depletion of the health system's capacity, and the economic downturn resulting from social distancing measures - alter the previous equilibrium in the responsibilities attributed to the different actors in the three instances of government, both regarding agenda-setting and coordination among actors to regulate health services in the country. At the federal level, it is possible to observe a conflict between two agendas: the adoption of measures to increase social distancing as the main policy to prevent the rapid spread of the disease, considering that there is no vaccine or treatment; and relaxing such measures in order to avoid economic collapse. Although experts point out that this conflict represents a false dichotomy, since successful social distancing policies enable a faster economic recovery (Arbix, Veiga, \& Barberia, 2020), this mindset caused paralysis in the $\mathrm{MH}$, which has failed to provide standards and coordinate actions to combat the pandemic at the national level. The inaction of the federal government has forced states - instances that deal directly with the impacts of the pandemic - to take a leading role and coordinate actions in their territories. The main instrument governors have used to conduct this endeavor has been the standardization of social distancing policies, offering guidelines to local authorities in the municipalities.

Therefore, it is possible to say that, in the face of the COVID-19 pandemic, the federal government lost space to the states both in the agenda-setting process and in the coordination among states and municipalities. More than a passive loss of space, the position of the federal government signals the political decision not to take responsibility based on a dualist and uncooperative view of the federalism in Brazil.

The notion of autonomy discussed in the debates about state capacity is an alternative to examine whether political or technical-administrative factors guide the leading role of the state governments in the fight against the COVID-19. In general, studies on state capacities observe how the state combines and activates resources, processes, and relationships to solve social problems and deliver effective public services (Gomide, Pereira, \& Machado, 2017; Gomide \& Pereira, 2018). The success factors of a government's action vary and may involve informational and budgetary resources ( $\mathrm{Wu}$, Ramesh, \& Howlett, 2015), quality of bureaucracy (Evans \& Rauch, 1999; Skocpol, 1985) and the relationship between the bureaucrats and non-state actors (Evans, 1993).

Part of the literature on state capacity considers that the autonomy of bureaucrats and politicians also contributes to the rationalization and effectiveness of government actions. Bureaucrats' autonomy is understood as the non-interference of short-term political interests in their performance, with technique predominating at the expense of political-electoral factors in policy decisions (Bersch, Praça, \& Taylor, 2017; Cingolani, Thomsson, \& Crombrugghe, 2015). The politicians' autonomy, in turn, is the independent performance of political leaders in relation to the interests of dominant social groups (Geddes, 1994; Skocpol, 1985).

This study took into account the autonomy of political leaders to understand the role of state governors in managing the COVID-19 pandemic. The assumption in this work is that the governors' autonomy favors scientific analyses prepared by specialized bureaucracies - such as monitoring the number of new infections and deaths, and the capacity of the local health system - to guide the decisions of local 
leaders, privileging the technique instead of short-term political interests. The study discusses the classic "politicians' dilemma" by Geddes (1994), where politicians face a conflict between their immediate needs regarding political survival and the long-term collective interests. In this model, politicians' autonomy is based on the strategic calculation between investment in policies leading to collective benefits in the long-term, and obtaining political support for purposes such as reelection, protection against possible coups, and approval of projects and programs. In the decision-making processes, political leaders would be less autonomous when choosing political support over technical rationality and evidence.

The debate on policy-making and subnational entities' autonomy emphasizes the political nature of the actions of state governments in a scenario in which patrimonialism and clientelism dominate the decision-making system (Abrucio, 1998; Hagopian, 1996). When adopting this rationale in the context of the fight against the COVID-19 pandemic, the governors' actions would be influenced by the attempt to gain political support to run in future elections, at the same time as avoiding retaliation from the incumbent and destabilizing their mandates.

The search for political support constitutes one of the biggest dilemmas for federations, which is the ability to share power between national and subnational governments, controlling so the rivalry does not destroy the country's unity. This is the dilemma between autonomy and sharing authority (Souza, 2019), and it takes various forms, for example, when governments from different instances blame one of them for unsuccessful implementation of public policies or when a government opportunistically take credits alone for collective achievement.

The governors' choice of gaining political support during the pandemic could be interpreted as a strategy to escape the attacks of the president (Coletta, Caram, \& Uribe, 2020; Pupo \& Resende, 2020) and avoid taking the blame for the economic effects of adopting social distancing measures, which would influence future electoral results, especially among Bolsonaro's voters. Another possible explanation for such a choice is the fear of receiving fewer funds from the federal government as a 'retaliation' from the president (Congresso em Foco, 2020).

The first hypothesis of this article, therefore, is that the greater the political and party alignment between state governors and the president, the more relaxed the social distancing policies. According to this assumption, the governors' option for a political approach would have less autonomy to follow the technical recommendations and acknowledge the evidence produced by their bureaucracies, such as monitoring the capacity of the local health system and the speed of contamination of the population in their jurisdiction.

However, recent studies on the state management of public policies have emphasized the autonomy of local leaders, and how the rationalization of these processes is supported by a professionalized bureaucracy, particularly in the case of subnational governments. Such actors are responsible for identifying and including local issues on a national agenda, regardless of the possible centralizing ties of the Brazilian federative model, which would restrict local authority when setting standards and norms for sensitive issues (Souza, 2019).

Thus, when studying variations in state income inequalities, Sátyro (2013) suggests that, although the federal government is the entity responsible for creating redistributive guidelines and policies, state secretaries have demonstrated autonomy in making changes that adjust these policies to regional needs and differences. The performance of local governments, however, is subject to fiscal limitations. For Segatto and Béland (2019), in the specific case of Brazilian public health, decentralization is 
dominant, although there are still traces of centralization, based mainly on how the public budget is structured in the country. In turn, Cardoso and Marenco (2019) point out that the professionalization of the public servants working in subnational entities is a decisive factor for achieving good results at local levels. The authors suggest that the technical work of these specialists is able to influence the decision-making process in policy-making.

The literature presented above supports the idea that the actions of state governments can be guided by technical-administrative factors rather than by political influences. The second hypothesis tested in this research is, therefore, when the national health system (SUS) is less structured in a state, this state adopts more rigorous social distancing measures to flatten the pandemic curve, seeking to increase the efficiency of the health system in place.

\section{RESULTS AND DISCUSSION}

After studying 134 regulations issued by Brazilian states, it was possible to create three categories of social distancing policies observed throughout the states (see Box 1). The content analysis carried out on the regulations focused on policies that restrict commerce and activities that may produce agglomeration. The analysis did not include restrictions on transportation (urban, rural, and intermunicipalities), nor the restrictions on the functioning of industries. It is also important to clarify that all the restrictive measures considered the exceptions applied to services considered as "essential activities," as provided in Law 13979 (2020).

The three categories separate states that adopted "soft measures," "rigorous measures," and those that adopted rigorous measures and are "inclined to relax" them. The category "soft measures" designates states that did not detail social distancing policies or decided to propose a low level of restriction (did not change these guidelines during the period of the analysis). The central measures in the policies in this category are school closures and the prohibition of activities that may produce agglomerations.

The category "rigorous measures" includes states that, in addition to soft policies, adopted a series of actions to suspend or restrict local commerce. The closing of shopping centers and the restrictions for restaurants and bars stand out. Some states in this category also closed gyms and beauty salons, and some states detailed the activities, places, and services with potential agglomerations that should be limited or prohibited, such as face-to-face religious activities, and cultural events. The states in this category started their actions to fight the pandemic with soft policies and, over time, included more restrictive measures.

The category "inclined to relax rigorous measures adopted" includes states whose first decrees were very restrictive. These governments started to re-open the commercial establishments and services previously prohibited. For example, in Rio Grande do Sul, on April 16, a new state decree (Decreto n. 55.128, 2020) allowed the opening of commercial establishments based on the reasons of municipal managers and scientific evidence. Rio de Janeiro determined clear relaxation with Decree 47025 (2020, our translation), of April 7, through which "[...] the operation of commercial establishments is authorized, in an unrestricted manner, in the municipalities that had, until the date of publication of this decree, no confirmed cases of coronavirus (COVID-19)." On April 11, 2020, Santa Catarina liberated street commerce. The Federal District has undergone gradual but constant measures to make trade more flexible (see Table 1). 


\begin{tabular}{|c|c|c|}
\hline $\begin{array}{l}\text { Categories } \\
\text { of social } \\
\text { distancing } \\
\text { policies }\end{array}$ & Main measures & States \\
\hline Soft measures & $\begin{array}{l}\text { School closures (MS; BA; TO); prohibition of activities that produce } \\
\text { agglomerations (MS; BA; TO); closure of state parks and sports } \\
\text { facilities (MS; TO); closure of cultural spaces such as museums and } \\
\text { cinemas (BA). }\end{array}$ & $\begin{array}{l}\text { Mato Grosso do Sul (MS); } \\
\text { Tocantins (TO); } \\
\text { Bahia (BA) }\end{array}$ \\
\hline $\begin{array}{l}\text { Rigorous } \\
\text { measures }\end{array}$ & $\begin{array}{l}\text { School closures (PA; PE; AL; CE; RR; AC; AM; MG; CE; RN; PR; ES; SE; PB; } \\
\text { PI; MA; SP); activities/events that produce agglomerations (PA; PE;AL; CE; } \\
\text { RR; AC; AM; MG; CE; RN; PR; ES; SE; PB; SP; MA; PI); malls, restaurants } \\
\text { and bars (food delivery and take out are permitted) (PA; PE; AL; CE; RR; } \\
\text { AC; AM; MG; CE; RN; PR; ES; SE; PB; MA; SP); churches/temples or } \\
\text { religious celebrations (except online) (PA; AL; CE; RR; AC; CE; RN; SE; } \\
\text { PB; PI; RR; SP); beaches, streams, and seaside locations, or prohibition } \\
\text { of commerce in these areas (PA; PE; CE; RN); gyms and similar facilities } \\
\text { (PA; PE; AL; CE; RR; AC; AM; MG; CE; PR; ES; SE; PB; MA; SP); cultural } \\
\text { spaces such as museums and cinemas (PE; AL; CE; RR; AC; AM; MG; CE; } \\
\text { RN; SE; PB; MA; SP); state parks and/or sports facilities (MG; RN; PI; SP); } \\
\text { local fairs and markets (PE; CE; AC; MG; CE); beauty salons and similar } \\
\text { businesses (AC; MG; SE); stores and commercial or services businesses } \\
\text { (AL; CE; AC; AM; CE; PB; PI); bank services (except online) (RN; ES; PB); } \\
\text { lottery retailers (PB). }\end{array}$ & $\begin{array}{c}\text { São Paulo (SP); } \\
\text { Amazonas (AM); } \\
\text { Roraima (RR); } \\
\text { Acre (AC); } \\
\text { Alagoas (AL); } \\
\text { Minas Gerais (MG); } \\
\text { Pará (PA); } \\
\text { Ceará (CE); } \\
\text { Rio Grande do Norte (RN); } \\
\text { Pernambuco (PE); } \\
\text { Paraná (PR); } \\
\text { Espírito Santo (ES); } \\
\text { Sergipe (SE); } \\
\text { Paraíba (PB); } \\
\text { Piauí (PI); } \\
\text { Maranhão (MA) }\end{array}$ \\
\hline $\begin{array}{l}\text { Inclined to } \\
\text { relax rigorous } \\
\text { measures } \\
\text { adopted }\end{array}$ & $\begin{array}{l}\text { School closures (AP; MT; RO; GO; DF; RJ; SC; RS); activities/events } \\
\text { that produce agglomerations (AP; MT; RO; GO; DF; RJ; SC; RS); malls, } \\
\text { restaurants and bars (food delivery and take out are permitted) (AP; MT; } \\
\text { RO; GO; DF; RJ; SC; RS); churches/temples or religious celebrations } \\
\text { (except online) (AP; MT; RO; GO; DF; RJ; SC; RS); beaches, streams, and } \\
\text { seaside locations, or prohibition of commerce in these areas (AP; MT; RJ); } \\
\text { gyms and similar facilities (AP; MT; DF; RJ; SC; RS); cultural spaces such } \\
\text { as museums and cinemas (AP; MT; RO; DF; RJ); state parks and/or sports } \\
\text { facilities (AP; MT; DF); local fairs and markets (AP; MT); beauty salon } \\
\text { and similar businesses (AP; GO; DF); stores and commercial or services } \\
\text { businesses (AP; RO; SC); bank services (except online) (DF). } \\
\text { Relaxing/permissions: lottery retailers (AP; MT; RO; DF); convenience } \\
\text { shops (AP; MT; DF); malls and commercial galleries (MT); funerals (MT); } \\
\text { bank services (MT); hotel and hospitality (RO; SC); local fairs and markets } \\
\text { (GO; DF, RJ); flower shops (DF); furniture stores (DF); appliances stores } \\
\text { (DF); commercial stores re-open for full operation in municipalities that } \\
\text { had no confirmed cases of coronavirus infection (RJ); street vending } \\
\text { (SC); barber shops and hair salons (RS); commerce, based on requisites } \\
\text { established by local authorities (RS). }\end{array}$ & $\begin{array}{c}\text { Amapá (AP); } \\
\text { Mato Grosso (MT); } \\
\text { Rondônia (RO); } \\
\text { Goiás (GO); } \\
\text { Distrito Federal (DF); } \\
\text { Rio de Janeiro (RJ); } \\
\text { Rio Grande do Sul (RS); } \\
\text { Santa Catarina (SC) }\end{array}$ \\
\hline
\end{tabular}

Source: Elaborated by the authors. 
From the perspective of the political factors, the analysis of the states considering the categories of social distancing policies shows that, among the sixteen states that implemented rigorous measures, six governors support the government or support the president or supported him in the 2018 presidential election. Two of them remained neutral during the elections and have been critics of the federal government. As for the eight states that are inclined to relax rigorous measures adopted, seven governors supported the election of Bolsonaro or support his government, and one opposes. In these cases, the restrictive measures predominate despite the inclination to relax. These states did not incorporate the president's suggestions, such as re-opening schools. Of the three states that implemented soft social distancing policies, one governor supports President Bolsonaro, the second opposes, and the third was neutral in the 2018 presidential election - even though there are signs of support for the president's government (Vilela, 2018) -, as shown in Box 2.

STATE GOVERNORS' POLITICAL POSITION TOWARD THE PRESIDENT VS SOCIAL DISTANCING POLICY ADOPTED

\begin{tabular}{|c|c|c|c|}
\hline Category & Support the president & $\begin{array}{l}\text { Oppose the } \\
\text { president }\end{array}$ & Neutral in 2020 \\
\hline Soft measures & MS & $\mathrm{BA}$ & $\begin{array}{c}\text { T0 (supported the president in } \\
\text { the } 2018 \text { election) }\end{array}$ \\
\hline Rigorous measures & AC, AM, MG, PR, RR, SP & $\begin{array}{l}\text { AL, CE, MA, PB, } \\
\text { PE, PI, RN, SE }\end{array}$ & $\begin{array}{c}\text { ES, PA (opposed the president } \\
\text { in the } 2018 \text { election) }\end{array}$ \\
\hline Inclined to relax rigorous measures adopted & DF, GO, MT, RJ, RO, RS, SC & AP & \\
\hline
\end{tabular}

Source: Elaborated by the authors.

When President Bolsonaro addressed the nation on March 24 (Planalto, 2020a), nineteen governors publicly criticized him; of these, seven are supporters, according to the applied criteria (AC, GO, MS, RJ, RS, SC, SP). Six governors who currently support the president (or supported him in the 2018 presidential election) declared they would not criticize his statements. However, all governors maintained the social distancing policies (AM, DF, MT, MG, PR, TO) - four of them applied rigorous measures, and two are in the category of the governors inclined to relax rigorous measures adopted. Only two governors who support the president did not take a position on his statements (RO, RR). One of them adopted rigorous measures, and the other is in the category of the states inclined to relax rigorous measures previously adopted.

The president's speech was severely criticized by most state governors, even those who supported the president in his election and had been collaborating with his government. ${ }^{4}$ Perhaps the most striking criticism among supporters came from the governor of the state of São Paulo, João Dória, ${ }^{5}$

\footnotetext{
${ }^{4}$ After the statement on March 24, President Bolsonaro addressed the nation two more times. One on March 31 (Planalto, 2020b) and the other on April 08 (Planalto, 2020c). The study focuses on the March 24 statement (Planalto, 2020a) due to its impact on public opinion. The speech raised much criticism in Brazilian society and among state governors. The other times the president addressed the nation, he adopted a milder tone and acknowledged the seriousness of the crisis but criticized the social distancing measures and reinforced the use of chloroquine to treat the disease.

${ }^{5}$ The governor of São Paulo, João Dória, was a supporter of Bolsonaro in the 2018 elections and during 2019. However, in February 2020, Bolsonaro broke the alliance with Dória for electoral reasons (both are potential candidates for the presidency in the 2022 elections) and because of divergence over state taxes on fuel.
} 
who regretted the terms used by the president and said that he divided the country with his position. President Bolsonaro brutally responded to Dória's criticism and accused him of being an electoral opportunist $(\mathrm{G} 1,2020)$. Another drastic break of alliance was the case of the governor of the State of Goias, Ronaldo Caiado, who called the presidential speech irresponsible and strongly criticized the president's position of "blaming others for an economic collapse," without taking his share of responsibility (Boghossian, 2020).

The analysis of the president's position regarding the states' measures to contain the spread of SARS-CoV-2 demonstrates that governors acted autonomously, disregarding the suggestions of the president and following the technical recommendations of the Ministry of Health $(\mathrm{MH})$ and the technical evidence provided by their own state secretaries. When considering the "politicians' dilemma" (Geddes, 1994) in a situation of severe health crisis and uncertainty, it was possible to observe that the governors did not prioritize the short-term political support in their strategic calculation to decide how to manage the pandemic. This result contradicts previous studies suggesting that the management of public policies at the subnational level is marked by political bargains and cronyism (Hagopian, 1996).

In addition, the federative dilemma of the autonomy versus authority (Souza, 2019) is observed. In this case, the president avoids taking responsibility for the economic crisis, blaming the state governors and the rigorous measures they adopted to increase social distancing and reduce the spread of the virus. President Bolsonaro's speech has weight and real meaning for the thousands of Brazilians who lost their jobs due to the pandemic. It has a political intention to distinguish the president from other political leaders managing the states, exposing the divergences. The president's behavior may bring negative effects to the autonomy of governors who continue to make technical decisions, exposing critical points of party and electoral politics. The president imposes rivalries and retaliation on those who disagree with him, eroding the potential for unity and preventing cooperation between federal entities in a time of sanitary and economic emergency.

From a technical-administrative point of view - particularly regarding the health system's capacity - the international experience in tackling the COVID-19 pandemic indicates that three factors contributed to the collapse of the health system in several countries: the speed that SARS-CoV-2 spread, the average length of hospital stay for each patient, and the demand for medical supplies. In Brazil, to avoid a healthcare collapse in the midst of the pandemic, the states started a race without appropriate planning, competing with each other and with the federal government for supplies and, above all, for ventilators (Amorim, 2020). As for the supply dispute, some of the state secretaries of health requested that the $\mathrm{MH}$ solve the problem by concentrating on the purchase of medical and hospital equipment. Another measure to avoid pressure on the system was to raise the population's awareness to prevent the abrupt increase in the number of cases.

The lack of supplies and the low number of health professionals aggravated the situation. For example, an ICU bed for an adult requires, at a minimum, an intensive care specialist to act as the technician in charge. ${ }^{6}$ Also, around $50 \%$ of the 4,500 ICU staff in the country, is located in only twenty cities. ${ }^{7}$

\footnotetext{
${ }^{6}$ Ordinance 3432 of August 12 (1998) from the Brazilian Ministry of Health.

${ }^{7}$ The following cities concentrate the largest number of intensive care professionals: São Paulo (15.2\%); Rio de Janeiro (6.3\%); Belo Horizonte (3.2\%); Salvador (2.8\%); Recife (2.3\%); Fortaleza (2.1\%); Goiânia (1.8\%); Porto Alegre (1.7\%); Campinas (1.7\%); Brasília (1.6\%); Curitiba (1.5\%); Belém (1.3\%); Natal (1.2\%); Manaus (1.2\%); Vitória (1.0\%); Ribeirão Preto (1.0\%); João Pessoa (1.0\%); Niterói (1.0\%); Florianópolis (0.9\%) and Teresina (0.9\%) (Data compiled from CNES-DataSUS).
} 
The fact that governors started acting individually, evidences unusually low coordination from the federal government regarding health care services - an area that traditionally counts on strong coordination and cooperation between the federal government and subnational entities. Therefore, this study analyzed the context in each state, identifying whether the social distancing policies involved more rigorous measures when the medical-hospital infrastructure was considered fragile and less likely to cope with the demands of the COVID-19 pandemic. Table 1 shows the proportion of ICU beds, ventilators, and ICU staff per inhabitant in each state.

As for the case of ICU beds, WHO sets the standard of one ICU bed for every ten thousand inhabitants. The DF is the area with the best structure, while Maranhão, Tocantins, Pará, Amapá, Amazonas, Acre, and Roraima do not meet this minimum proportion. The discrepancy among the states is also observed in the distribution of ventilators. While São Paulo has one for every 28,137 inhabitants, Maranhão has one for every 262,044 inhabitants.

\section{TABLE $1 \quad$ PROPORTION EQUIPMENT, STAFF, BEDS AND NUMBER OF DEATHS PER STATE}

\begin{tabular}{|c|c|c|c|c|c|c|}
\hline State & Type of policy & ICU beds & ICU staff & Ventilators & Cases & Deaths \\
\hline Acre & Rigorous & 15205.8 & 40088.0 & 5802.2 & 110 & 5 \\
\hline Alagoas & Rigorous & 8646 & 98157.6 & 5855.0 & 89 & 5 \\
\hline Amapá & $\begin{array}{l}\text { Inclined to relax rigorous measures } \\
\text { adopted }\end{array}$ & 14334.4 & 120818.7 & 8997.1 & 362 & 9 \\
\hline Amazonas & Rigorous & 15181.7 & 67944.2 & 4610.2 & 1719 & 124 \\
\hline Bahia & Soft & 6729.9 & 79535.1 & 4489.3 & 951 & 30 \\
\hline Ceará & Rigorous & 7270.8 & 80105.9 & 4267.3 & 2386 & 124 \\
\hline Distrito Federal & $\begin{array}{l}\text { Inclined to relax rigorous measures } \\
\text { adopted }\end{array}$ & 3270.4 & 41878.7 & 1405.7 & 716 & 20 \\
\hline Espírito Santo & Rigorous & 4918.8 & 33488.8 & 2706.2 & 754 & 22 \\
\hline Goiás & $\begin{array}{l}\text { Inclined to relax rigorous measures } \\
\text { adopted }\end{array}$ & 5610.2 & 55701.2 & 4035.9 & 318 & 16 \\
\hline Maranhão & Rigorous & 11831.4 & 262043.7 & 6581.6 & 695 & 37 \\
\hline Mato Grosso & $\begin{array}{l}\text { Inclined to relax rigorous measures } \\
\text { adopted }\end{array}$ & 4455.8 & 49778.1 & 2478.3 & 156 & 5 \\
\hline Mato Grosso do Sul & Soft & 7572.2 & 59127.4 & 3037.1 & 131 & 5 \\
\hline Minas Gerais & Rigorous & 6629.7 & 52922.0 & 3358.5 & 958 & 33 \\
\hline Pará & Rigorous & 13655.3 & 92503.9 & 5896.4 & 438 & 24 \\
\hline Paraíba & Rigorous & 8604.1 & 61817.3 & 4353.3 & 165 & 24 \\
\hline Paraná & Rigorous & 4471.6 & 56885.4 & 3022.5 & 832 & 41 \\
\hline Pernambuco & Rigorous & 4954.4 & 67780.6 & 3052.4 & 1683 & 160 \\
\hline
\end{tabular}




\begin{tabular}{|c|c|c|c|c|c|c|}
\hline State & Type of policy & ICU beds & ICU staff & Ventilators & Cases & Deaths \\
\hline Piauí & Rigorous & 8943.2 & 69643.1 & 7273.8 & 91 & 8 \\
\hline Rio de Janeiro & $\begin{array}{l}\text { Inclined to relax rigorous measures } \\
\text { adopted }\end{array}$ & 3795.3 & 34323.9 & 2210.3 & 3944 & 300 \\
\hline Rio Grande do Norte & Rigorous & 7525.4 & 49392.3 & 4292.4 & 400 & 20 \\
\hline Rio Grande do Sul & Rigorous & 6457 & 50565.5 & 3275.9 & 780 & 19 \\
\hline Rondônia & $\begin{array}{l}\text { Inclined to relax rigorous measures } \\
\text { adopted }\end{array}$ & 7224.5 & 52271.3 & 3822.0 & 76 & 3 \\
\hline Roraima & Rigorous & 24230.4 & 46597.0 & 3985.3 & 142 & 3 \\
\hline Santa Catarina & $\begin{array}{l}\text { Inclined to relax rigorous measures } \\
\text { adopted }\end{array}$ & 6882.6 & 44227.1 & 3268.6 & 884 & 29 \\
\hline São Paulo & Rigorous & 4650.5 & 28136.7 & 2462.1 & 11568 & 853 \\
\hline Sergipe & Rigorous & 9014.5 & 63852.7 & 4264.7 & 48 & 4 \\
\hline Tocantins & Soft & 12582.9 & 112347.6 & 4824.7 & 29 & 1 \\
\hline
\end{tabular}

Source: Elaborated by the authors based on DataSUS and the Brazilian Ministry of Health (2020).

The number of cases and deaths is not directly related to the medical-hospital structure of each state. These numbers are proportionally distributed across the country: the larger the population, the greater the incidence of cases and deaths. ${ }^{8}$ The number of hospital beds, ICU beds, and ventilators has a direct influence on the number of deaths from the moment the system collapses. The governors' social distancing policies to reduce the spread of the virus were justified considering that the expansion of the system during the pandemic comes up against economic and logistic barriers and a low supply of human resources (intensive care doctors, for example).

\section{TABLE 2 AVERAGE EQUIPMENT, STAFF, BEDS, AND CASES PER TYPE OF POLICY}

\begin{tabular}{|c|c|c|c|c|c|}
\hline \multirow{2}{*}{ Type of policy } & ICU beds & ICU staff & Ventilators & Cases & Deaths \\
\hline & Average & Average & Average & Average & Average \\
\hline Soft measures & 8961.7 & 83670.0 & 4117.0 & 370.3 & 12.0 \\
\hline Rigorous measures & 9540.6 & 71877.9 & 4415.3 & 1344.6 & 88.6 \\
\hline $\begin{array}{l}\text { Inclined to relax rigorous measures } \\
\text { adopted }\end{array}$ & 6510.5 & 56999.9 & 3745.4 & 922.3 & 54.6 \\
\hline
\end{tabular}

Source: Elaborated by the authors based on data collected on April 16, 2020, from DataSUS and the Brazilian Ministry of Health.

\footnotetext{
${ }^{8}$ The correlation between population and number of cases is 0.896 , and between population and number of deaths is 0.873 .
} 
Table 2 shows that the states that adopted rigorous measures are the least prepared for the outbreak. On average, they have one ICU bed for every 9,540.6 inhabitants. Those who opted for soft measures have one ICU bed for every 8,961.7, and those states considered inclined to relax rigorous measures adopted have one ICU bed for every 6,510 inhabitants. This same trend is repeated in relation to the average number of ventilators. Finally, the states with less infrastructure in health that adopted rigorous policies were also those with the highest number of cases and deaths. The states that have better infrastructure and adopted soft policies showed the lowest average of cases and deaths in the analyzed period.

These data show that the leadership of governors in relation to social distancing policies in the context of the COVID-19 pandemic was guided by technical evidence, which demonstrates the autonomy of state leaders. The data corroborate recent studies pointing out that policy-making in subnational entities is marked by the autonomy of local leaders and by the rationalization of the process, based on the technical influence of a professionalized bureaucracy (Cardoso \& Marenco, 2019; Sátyro, 2013).

\section{FINAL CONSIDERATIONS}

In Brazil, the health crisis caused by COVID-19 demanded quick responses from political leaders and managers in the context of a strong dispute between technical and political arguments to guide public actions. Based on the notion of "punctuated equilibrium," this research analyzed the health policy-making in Brazil. The socioeconomic disruption generated by the COVID-19 pandemic broke with the previous equilibrium supported by the concentration of multiple functions in the federal government, such as agenda-setting, coordination with the states, and promotion of cooperation among them (Brasil \& Capella, 2019; Menicucci, 2014; Souza, 2019). Thus, in the current scenario, the governors took responsibility for these functions, enacting regulations and standards to implement social distancing policies, guiding and coordinating the municipalities. Faced with this innovation, produced in the context of a strong health crisis, this article examined whether the leadership of state governments was based on technical-administrative factors or political influences.

No evidence was found to support the hypothesis of the relationship between the relaxing of social distancing policies and the greater political-party alignment of state governors to the president. It was possible to observe a significant number of governors politically aligned with President Bolsonaro, who adopted rigorous measures to ensure social distancing among the population. Although the majority of the states in the category 'inclined to relax rigorous measured adopted' are governed by leaders that support the president, the relaxing measures considered do not incorporate the president's suggestion for broad re-opening of schools and economic activities.

The findings contradict previous studies that relate the management of subnational entities to political bargaining and practices of clientelism (Abrucio, 1998; Hagopian, 1996). However, the conflict between President Bolsonaro and the state governors who maintain social distancing policies is significant, since the president's accusations are serious enough to produce electoral losses. This conflict also affects the governors' degree of autonomy in continuing to make technical decisions to contain the spread of the virus and the overload of the health system. The president's behavior imposes one of the most powerful dilemmas on federations, that of autonomy versus the sharing of authority. 
It is important to encourage studies that seek to understand the peculiarities of the disruptions caused by the pandemic and its influence on the behavior of governors, particularly examining the standardization or the exceptionality of the procedures related to health care services. Furthermore, new research must focus on monitoring the processes of relaxing social distancing measures in the states, investigating the reasons behind the decisions made, if related to the economic impact, political pressure, or others.

The research corroborated the hypothesis that less health infrastructure in a state leads to more rigorous social distancing measures, and confirmed studies such as the works by Cardoso and Marenco (2019) and Sátyro (2013), that pointed to an increasing rationalization and autonomy in the management of subnational entities.

The data collected reveal that faced with the "politicians' dilemma" (Geddes, 1994), the governors opted for investment in capacities and rationalization of the policy, taking into account the technical information produced by specialized bureaucracies at the expense of political support from the president. The governors' choice reinforced their autonomy to act according to the WHO's scientific recommendations and following the guidelines offered by Brazilian bureaucracies - Ministry of Health and state secretaries of health - instead of submitting to political bargains and disregarding scientific evidence.

This research observes a specific time frame, restricted to the period from the moment the authorities recognized COVID-19 as a pandemic to the dismissal of the former Minister of Health Luiz Henrique Mandetta, a period, characterized by the strong defense of technical and scientific solutions by the Ministry of Health (MH). It is possible to notice some changes in the types of social distancing policies adopted by the states after the period analyzed in this study. States categorized here as adopting rigorous measures have recently demonstrated to be inclined to relax and re-start activities as of May 2020, as is the case in the state of São Paulo. There are also states, such as Santa Catarina, that were already inclined to relax rigorous measures and, within a few weeks after the period examined in this study, re-opened the commerce, converting their policies from rigorous to soft, precisely at a time of rising numbers, contamination, and deaths caused by COVID-19.

The relationship between the changes in the MH's leadership and the positions of the governors instigates future research that helps to understand new configurations in the influence of political and technical factors in health policy-making. Equally important is the investigation of two themes: the quality of state bureaucracies that contribute to the leadership of governors in policy-making in the face of the COVID-19 pandemic; and the loss of MH's capacity to regulate the sector nationwide and, consequently, its capacity to conduct robust federative coordination.

Thus, future studies could address the following questions: Is it possible to say that the states counting on more professionalized bureaucracies in the area of health had a better performance from their social distancing policies? How did the president's action reduce the autonomy of the Ministry of Health to regulate and coordinate subnational entities in combating the COVID-19 pandemic? 


\section{REFERENCES}

Abrucio, F. L. (1998). Os Barões da Federação: os governadores e a redemocratização brasileira. São Paulo, SP: Hucitec, 1998.

Abrucio, F. L. (2005). A Coordenação Federativa no Brasil: a experiência do período FHC e os desafios do governo Lula. Revista de Sociologia Política, 24, 41-67.

Agência Brasil. (2020, March 11). Organização Mundial da Saúde declara pandemia de coronavírus. Atualmente, ao menos 115 países têm casos da doença. Retrieved from https://agenciabrasil.ebc.com.br/ geral/noticia/2020-03/organizacao-mundial-dasaude-declara-pandemia-de-coronavirus

Amorim, F. (2020, March 26). Governo centraliza estoque de respiradores e gera atrito com estados. UOL (Notícias). Retrieved from https://noticias. uol.com.br/politica/ultimas-noticias/2020/03/26/ governo-centraliza-estoque-de-respiradores-e-geraatrito-com-estados.htm

Arbix, G., Veiga, J. P., \& Barberia, L. (2020, April 30). Falta de coordenação entre o governo federal e estados enfraquecem a política de distanciamento social. A flexibilização sem critérios pode agravar a pandemia. Covid-19: Politicas Públicas e as Respostas da Sociedade (Rede de Pesquisa Solidária, boletim 4). São Paulo, SP: Políticas Públicas \& Sociedade.

Arretche, M. T. S. (1999). Políticas sociais no Brasil: descentralização em um Estado Federativo. Revista Brasileira de Ciências Sociais, 14(40), 111-141.

Arretche, M. T. S. (2004). Federalismo e políticas sociais no Brasil: problemas de coordenação e autonomia. São Paulo Em Perspectiva, 18(2), 17-26.

Baumgartner, F. R., \& Jones, B. D. (Ed.). (2002). Policy dynamics. Chicago, Illinois: University of Chicago Press.

Bersch, K., Praca, S., \& Taylor, M. M (2017). State Capacity, Bureaucratic Politicization, and Corruption in the Brazilian State. Governance: an International Journal of Policy, Administration, and Institutions, 30(1), 105-124.

Bichir, R. M. (2016). Novos instrumentos de coordenação federativa: reflexões a partir do Programa Bolsa Família. Revista Brasileira de Políticas Públicas e Internacionais, 1, 49-78.
Boghossian, B. (2020, March 25). Caiado rompe com Bolsonaro e diz que não respeitará decisões do presidente. Folha de São Paulo. Retrieved from https://www1.folha.uol.com.br/poder/2020/03/ caiado-rompe-com-bolsonaro-e-diz-que-naorespeitara-decisoes-do-presidente.shtml

Brasil, F., \& Capella, A. C. (2019). A dinâmica da atenção governamental sobre as políticas de saúde no Brasil: equilíbrio pontuado nas primeiras décadas pós-redemocratização (1986-2003). Saúde e Sociedade, 28(3), 80-96.

Cardoso, A. L. R., \& Marenco, A. (2019). Qualidade Burocrática e Performance Estatal: desvendando a caixa preta do município. Administração Pública e Gestão Social, 11(4), 1-21. Retrieved from https:// periodicos.ufv.br/apgs/article/view/6318

Cingolani, L., Thomsson, K., \& Crombrugghe, D. (2015). Minding Weber more than ever? The impacts of state capacity and bureaucratic autonomy on development goals. World Development, 72, 191-207.

Colleta, R. D., Caram, B., \& Uribe, G. (2020, May 14). É guerra, tem que jogar pesado com governadores, diz Bolsonaro a empresários. Folha de São Paulo. Retrieved from https://www1.folha.uol.com.br/ poder/2020/05/e-guerra-tem-que-jogar-pesadocom-governadores-diz-bolsonaro-a-empresarios. shtml

Congresso em Foco. (2020, June 03). Bolsonaro veta repasse de $R \$ 8,6$ bilhões para estados e municípios. Retrieved from https://congressoemfoco.uol. com.br/governo/bolsonaro-veta-repasse-de-r-86bilhoes-para-estados-e-municipios/

DataSUS. (2020, May 06). Cadastro Nacional de Estabelecimentos de Saúde. Retrieved from http:// cnes2.datasus.gov.br/

Decreto Distrital n. 40.509 de 12 de março de 2020, do Governo do Distrito Federal. (2020). Dispõe sobre as medidas para enfrentamento da emergência de saúde pública de importância internacional decorrente do novo coronavírus e dá outras providências. Brasília, DF. Retrieved from http://www.sinj.df.gov.br/ SINJ/Norma/ad0fae78af5f4e50b46c7357b7ee8597/ Decreto_40509_11_03_2020.html

Decreto Estadual n. 55.128, de 19 de março de 2020, do Governo do Rio Grande do Sul. (2020). Declara estado de calamidade pública em todo o território do Estado do Rio Grande do Sul para fins de 
prevenção e de enfrentamento à epidemia causada pelo COVID-19 (novo Coronavírus), e dá outras providências. Retrieved from https://cremers.org.br/ wp-content/uploads/2020/03/19.03.2020-Decreton\%C2\%BA-55128-do-governo-do-Estado.pdf

Decreto Estadual n. 1415, de 22 de março de 2020, do Governo do Amapá. (2020). Altera o Decreto Estadual $\mathrm{n}^{\circ} 1.414$ de 19 março de 2020, que dispõe sobre restrições de funcionamento para o fim de combater a disseminação do novo Coronavírus (COVID-19) no território do Estado do Amapá. Retrieved from https://www.legisweb.com.br/ legislacao/?id=391457

Decreto Estadual n. 24.891, de 23 de março de 2020, do Governo de Rondônia. (2020). Altera e acrescenta dispositivos do Decreto ${ }^{\circ} 24.887$, de 20 de março de 2020. Retrieved from http://www.rondonia.ro.gov. br/publicacao/decreto-no-24-891/

Decreto Estadual $n^{\circ} 425$, de 25 de março de 2020, do Governo do Mato Grosso do Sul. (2020). Consolida as medidas temporárias restritivas às atividades privadas para prevenção dos riscos de disseminação do Coronavírus (COVID-19) e dá outras providências. Retrieved from https://www. legisweb.com.br/legislacao/ id= $=391758$

Decreto Estadual n. 29.583, de $1^{\circ}$ de abril de 2020, do Governo do Rio Grande do Norte. (2020). Consolida as medidas de saúde para o enfrentamento do novo coronavírus (COVID-19) no âmbito do Estado do Rio Grande do Norte e dá outras providências. Retrieved from https://www.legisweb.com.br/ legislacao/?id=392200

Decreto Estadual no 9.645, de 03 de abril de 2020, do governo do Goiás. (2020). Altera o Decreto n. 9.633, de 13 de março de 2020. Retrieved from https://legisla. casacivil.go.gov.br/pesquisa_legislacao/103080

Decreto Estadual n. 47.025, de 07 de abril de 2020, do Governo do Rio de Janeiro. (2020). Dispõe sobre a liberação de atividade comercial em municípios sem notificação de cometimento do Covid-19, e dá outras providências. Retrieved from https://www. legisweb.com.br/legislacao/?id=392689

Decreto n. 64.881, de 20 de março de 2020, do Governo de São Paulo. (2020). Decreta quarentena no Estado de São Paulo, no contexto da pandemia do COVID-19 (Novo Coronavírus), e dá providências complementares. Retrieved from https://www.al.sp. gov.br/norma/193361
Draibe, S. M. (2005). Ciclos de reformas de políticas públicas em ambiente de consolidação da democracia: a experiência brasileira recente de reforma dos programas sociais. Campinas, SP: Unicamp.

Estadão. (2020, June 04). Em novo estudo, cloroquina não apresenta efeitos significativos no combate à covid-19. Retrieved from https://saude.estadao. com.br/noticias/geral,em-novo-estudo-cloroquinanao-apresenta-efeitos-significativos-no-combate-acovid-19,70003324318

Evans, P. (1993). O Estado como problema e solução. Lua Nova: Revista de Cultura e Política, 28-29, 107-157.

Evans, P., \& Rauch, J.E. (1999, October). Bureaucracy and growth: a cross-national analysis of the effects of "Weberian" state structures on economic growth. American Sociological Review, 4(5), 748-765.

Folha de S. Paulo. (2020, May 15). Após ultimato sobre cloroquina, Teich pede demissão do Ministério da Saúde. Retrieved from https://www1.folha.uol.com. br/equilibrioesaude/2020/05/apos-ultimato-sobrecloroquina-teich-pede-demissao-do-ministerioda-saude.shtml

Folha de Pernambuco. (2020, April 14). Governo Bolsonaro recorre ao STF para que estados e municípios sigam regras federais de isolamento. Retrieved from https://www.folhape.com.br/POLITICA/2193GOVERNO-BOLSONARO-RECORRE-STFPARA-QUE-ESTADOS-MUNICIPIOS-SIGAMREGRAS-FEDERAIS-ISOLAMENTO/137219/

Geddes, B. (1994). Politician's Dilemma: Building State Capacity in Latin America. Berkeley, CA: University of California Press.

Gomide, A. A., Pereira, A. K., \& Machado, R. A. (2017). Capacidade estatal e a pesquisa científica: contribuições do dossiê temático. Sociedade e Cultura, 20, 3-12.

Gomide, A., \& Pereira, A. K (2018). Capacidades estatais para políticas de infraestrutura no Brasil contemporâneo. Revista de Administração Pública, 52(5), 935-955.

G1. (2020, March 25). Doria e Bolsonaro discutem em reunião de governadores. Governador de São Paulo fez duras críticas ao presidente por pronunciamento minimizando coronavírus. Retrieved from https:// g1.globo.com/jornal-nacional/noticia/2020/03/25/ doria-e-bolsonaro-discutem-em-reuniao-degovernadores.ghtml 
Hagopian, F. (1996). Traditional politics and regime change in Brazil. Cambridge, UK: Cambridge University Press.

Lei n. 13.979, de 6 de fevereiro de 2020. (2020). Dispõe sobre as medidas para enfrentamento da emergência de saúde pública de importância internacional decorrente do coronavírus responsável pelo surto de 2019. Retrieved from http://www.planalto.gov. br/ccivil_03/_ato2019-2022/2020/lei/L13979.htm

Lindblom, C. (1959). The Science of Muddling Through. Public Administration Review, 19(2), 79-88.

Linhares, C., \& Barbon, J. (2020, April 18). Carreata em SP mira Doria e Maia em meio a pedidos de intervenção militar. Folha de São Paulo. Retrieved from https://www1.folha.uol.com.br/ poder/2020/04/carreata-em-sp-mira-doria-e-maiaem-meio-a-pedidos-de-intervencao-militar.shtml

Menicucci, T. M. G. (2007). Os Argumentos Analíticos: A Perspectiva Histórica e Institucional. In Menicucci, T. M. G., Público e Privado na Política de Assistência à Saúde no Brasil: Atores, processos e trajetória (Cap. XX, pp. 21-56). Rio de Janeiro, RJ: Editora Fiocruz.

Menicucci. T. M. G. (2014). Cooperação e coordenação na implementação de políticas públicas: as relações intergovernamentais na regionalização da assistência à saúde. In Anais do 90 Encontro da $A B C P$, Brasília, DF.

Menicucci, T. M. G., Costa, L. A., \& Machado, J. A. (2018). Pacto pela saúde: aproximações e colisões na arena federativa. Ciência e Saúde Coletiva, 23(1), 29-40.

Pierson, P. (1993). When effect becomes cause: policy feedback and political change. World Politics, 45(1), 595-628.

Pierson, P. (1994). Dismantling the Welfare State? Reagan, Thatcher, and the Political Retrenchment. Cambridge, UK: Cambridge University press.

Pinheiro, R. (2020, April 16). STF reconhece competência de estados e municípios em regras de isolamento. Rádio Senado (Notícias). Retrieved from https://www12.senado.leg.br/radio/1/noticia/stfreconhece-competencia-concorrente-de-estados-dfmunicipios-e-uniao-no-combate-a-covid-19

Pires, R. R. C., \& Gomide, A. A. (2014). Capacidades estatais e democracia: a abordagem dos arranjos institucionais para análise de políticas públicas. In Pires, R. R. C., Gomide, A. A. (Eds.), Capacidades estatais e democracia: arranjos institucionais de políticas públicas (v. 1, pp. 15-30). Brasília, DF: Ipea.

Planalto. (2020a, March 24). Pronunciamento do presidente da República, Jair Bolsonaro, em Cadeia de Rádio e Televisão, em 24/03/2020. Pronunciamento apresentado por Jair Bolsonaro. [Brasília, DF], 2020. 1 vídeo (4min 58seg). Publicado pelo canal do Palácio do Planalto. Retrieved from https://www. youtube.com/watch?v=Vl_DYb-XaAE

Planalto. (2020b, March 31). Pronunciamento do presidente da República, Jair Bolsonaro, em Cadeia de Rádio e Televisão, em 31/03/2020. Pronunciamento apresentado por Jair Bolsonaro. [Brasília, DF], 2020. 1 vídeo (7min 29seg). Publicado pelo canal do Palácio do Planalto. Retrieved from https://www. youtube.com/watch?v=16RR2rG_AKA

Planalto. (2020c, April 08). Pronunciamento do presidente da República, Jair Bolsonaro, em Cadeia de Rádio e Televisão, em 08/04/2020. Pronunciamento apresentado por Jair Bolsonaro. [Brasília], 2020. 1 vídeo (5min 10seg). Publicado pelo canal do Palácio do Planalto. Retrieved from https://www.youtube. com/watch?v=x04OKkxT2Tc

Portaria n. 188, de 3 de fevereiro de 2020, do Ministério da Saúde. (2020). Declara Emergência em Saúde Pública de importância Nacional (ESPIN) em decorrência da Infecção Humana pelo novo Coronavírus (2019-nCoV). Retrieved from http:// www.in.gov.br/en/web/dou/-/portaria-n-188-de-3de-fevereiro-de-2020-241408388

Portaria n. 356, de 11 de março de 2020, do Ministério da Saúde. (2020). Dispõe sobre a regulamentação e operacionalização do disposto na Lei ${ }^{\circ} 13.979$, de 6 de fevereiro de 2020, que estabelece as medidas para enfrentamento da emergência de saúde pública de importância internacional decorrente do coronavírus (COVID-19). Retrieved from http:// www.in.gov.br/en/web/dou/-/portaria-n-356-de-11de-marco-de-2020-247538346

Portaria n. 454, de 20 de março de 2020, do Ministério da Saúde. (2020). Declara, em todo o território nacional, o estado de transmissão comunitária do coronavírus (covid-19). Retrieved from http://www. in.gov.br/en/web/dou/-/portaria-n-454-de-20-demarco-de-2020-249091587

Portaria n. 3.432, de 12 de agosto de 1998, do Ministério da Saúde. (2020). Estabelece critérios de classificação 
para as Unidades de Tratamento Intensivo - UTI. Retrieved from http://bvsms.saude.gov.br/bvs/ saudelegis/gm/1998/prt3432_12_08_1998.html

Pupo, F., \& Resende, T. (2020, June 03). Bolsonaro veta repasse de $\mathrm{R} \$ 8,6$ bi para estados e municípios combaterem coronavírus. Folha de São Paulo. Retrieved from https://www1.folha.uol.com.br/ mercado/2020/06/bolsonaro-veta-repasse-de-r86-bi-para-estados-e-municipios-combateremcoronavirus.shtml

Sátyro, N. G. D. (2013). Política estadual e desigualdade: por que alguns estados redistribuem mais do que outros? Dados, 56(3), 497-530.

Skocpol, T. (1985). Bringing the State Back In: Strategies of Analysis in Current Research. In P. Evans, D. Rueschemeyer, \& T. Skocpol (Eds.), Bringing the State Back In (pp. 3-38). Cambridge, UK: Cambridge University Press. Retrieved from https://doi.org/10.1017/CBO9780511628283.002

Segatto, C. I., \& Béland, D. (2019, June). Federalism and decision making in health care: the influence of subnational governments in Brazil. Policy Studies, 1-19. Retrieved from https://doi.org/10.1080/0144 2872.2019.1634187

Souza, C. (2004). Governos locais e gestão de políticas sociais universais. São Paulo em Perspectiva, $18(2), 27-41$.

Souza, C. (2019, June 17). Coordenação, uniformidade e autonomia na formulação de políticas públicas: experiências federativas no cenário internacional e nacional. Caderno de Saúde Pública, 35(supl. 2), e00046818. Retrieved from https://doi.org/10.1590/0102-311x00046818

Vilela, P. R. (2020, October 28). Bolsonaro recebeu apoio de 15 dos 27 governadores eleitos. Agência Brasil. Retrieved from https://agenciabrasil.ebc.com. br/politica/noticia/2018-10/bolsonaro-recebeuapoio-de-15-dos-27-governadores-eleitos

Wu, X., Ramesh, M., \& Howlett, M. (2015). Policy capacity: a conceptual framework for understanding policy competences and capabilities. Policy and Society, 34(3-4), 165-171.

\section{Ana Karine Pereira}

https://orcid.org/0000-0002-7282-6122

Ph.D. in Political Science from University of Brasília (UnB); Adjunct professor at the Center for Sustainable Development at University of Brasília (UnB); Permanent professor of the Graduate Programs in Political Science (PPGCP) and in Administration (PPGADM) at Federal University of Goiás (UFG).

E-mail: ana.pereira@unb.br

\section{Marília Silva Oliveira}

https://orcid.org/0000-0002-1055-781X

Ph.D. and postdoctoral student in Political Science from the Political Science Institute of University of Brasília (UnB). E-mail: mariliasoliveira@gmail.com

\section{Thiago da Silva Sampaio}

https://orcid.org/0000-0003-1178-0746

Ph.D. in Political Science from Federal University of Minas Gerais (UFMG); Adjunct professor of the Postgraduate Program in Public Policy at Federal University of Pampa (UNIPAMPA).

E-mail: thiagosampaio@unipampa.edu.br 